\title{
Enflasyon-Gelir Eşitsizliği İlişkisi: Gelişmiş ve Gelişmekte Olan Ülkeler için Panel Eşik Değer Analizi
}

\author{
Emin Efecan AKTAŞ (https://orcid.org/0000-0001-7751-3275), Hatay Mustafa Kemal University, Turkey; \\ efecanaktas@yahoo.com \\ Sevi DOKUZOĞLU (https://orcid.org/0000-0002-2888-4755), Hatay Mustafa Kemal University, Turkey; \\ sdokuzoglu@mku.edu.tr

\section{Inflation-Income Inequality Nexus: Panel Threshold Analysis for Developed and Developing Countries}

\begin{abstract}
Most of the studies focusing on the differences between countries in income inequality indicate that the explanatory power of empirical analysis can be increased by including monetary policy variables such as inflation level, inflation level flexibility and interest rate into economic models. Particularly, the distributional effects of inflation have become a major topic. The aim of the study is to analyze the non-linear effects of inflation on income inequality. In this context, panel threshold analysis has been implemented for 40 developed and developing countries in the period of 1993-2019. It is concluded that the aspect of the income inequality is determined by the inflation level. The consumer price index $(2010=100)$ has been defined as the inflation indicator, and significant levels with single $(49,300)$ and double $(45,000)$ thresholds have been detected. Besides, estimates have been repeated with another inequality indicator for robustness check and similar results have been obtained. The relationship between inflation and income inequality is in the inverse (negative) aspect below the threshold inflation level and in the same (positive) aspect above it. The analysis confirms the existence of nonlinear effects and contributes to literature samples.
\end{abstract}

Keywords : Income Inequality, Inflation, Panel Threshold Analysis.

JEL Classification Codes : $\quad$ D63, E31, C24, C33.

Öz

Gelir eşitsizliğine ilişkin ülkeler arası farklılıkların konu edildiği çalışmaların çoğu ampirik analizlerin açıklayıcılık gücünün enflasyon seviyesi, enflasyon oranı esnekliği ve faiz oranı gibi para politikası değişkenlerinin iktisadi modellere dâhil edilerek artırılabileceğine işaret etmektedir. Özellikle, enflasyonun dağıtımsal etkileri önemli bir konu haline gelmiştir. Çalışmanın amacı, enflasyonun gelir eşitsizliği üzerindeki doğrusal olmayan etkilerinin analiz edilmesidir. Bu çerçevede, 1993-2019 yıllarını kapsayan dönemde 40 adet gelişmiş ve gelişmekte olan ülke grubu için panel eşik değer analizi gerçekleştirilmiştir. Gelir eşitsizliğinin yönünü enflasyon seviyesinin belirlediği sonucuna ulaşı1mıştır. Enflasyon değişkeni olarak tüketici fiyatları endeksi $(2010=100)$ tanımlanmış olup tek $(49,300)$ ve çift $(45,000)$ eşikli anlamlı seviyeler tespit edilmiştir. Ayrıca, sağlamlık kontrolü adına tahminler bir diğer eşitsizlik göstergesi ile yinelenmiş ve benzer sonuçlara ulaşılmıştır. Enflasyonun gelir eşitsizliği ile ilişkisi, eşik enflasyon seviyesinin altında ters (negatif) yönlü, üzerinde ise aynı (pozitif) yönlüdür. Analiz, doğrusal olmayan etkilerin varlığını doğrulamakta olup literatür örneklerine katkı sağlamaktadır.

Anahtar Sözcükler $\quad$ : Gelir Eşitsizliği, Enflasyon, Panel Eşik Değer Analizi. 
Aktaş, E.E. \& S. Dokuzoğlu (2022), "Enflasyon-Gelir Eşitsizliği İlişkisi: Gelişmiş ve Gelişmekte Olan Ülkeler için Panel Eşik Değer Analizi”, Sosyoekonomi, 30(51), 449-470.

\section{Giriş}

Gelir dağılımına ilişkin çok sayıda çalışmada Kuznets (1955) ile ortaya koyulan hipotezin ülkeler arası gelir eşitsizliği farklılıklarının sınırlı bir bölümünü açıklayabildiği; vergi ve harcama politikaları, sosyal transferler, beşeri sermaye ve kamu istihdamı gibi politik ve yapısal değişkenlerin söz konusu farklılıkları açıklamakta daha etkili olduğu ortaya koyulmuştur (Milanovic, 1994; Chu et al., 2000). Özellikle, politik iktisat literatüründe gelirin yeniden dağıtımı, kamunun vergi ve transfer ödemeleri aracılığıyla gerçekleşen maliye politikası uygulamaları ile ilişkilendirilmiştir (Atkinson, 1996; Gottschalk \& Smeeding, 1997; Caminada et al., 2017). Bununla birlikte, yapışkan fiyatların, ücret katılıklarının, eksik piyasaların ve hanehalkları arasındaki heterojenliğin analizlere dâhil edilmesiyle birlikte makroekonomik politikaların ve şokların gelir eşitsizliği üzerinde yarattığı etkilere ilişkin yeni bir paradigma ortaya çıkmıştır. Böylece para politikasının da dağıtımsal etkileri önem kazanmıştır (Ribba, 2003; Balcılar et al., 2018; Colciago et al., 2019). Bu çerçevede, para politikası enflasyon, tasarrufların yeniden dağılımı, faiz oranı riski, portföy kompozisyonu, hanehalklarının heterojen yapısı ve gelir kompozisyonu gibi kanallar ile gelir ve servet eşitsizliği üzerinde etkiler yaratmaktadır (Colciago et al., 2019: 1213).

Paranın satınalma gücünde meydana gelen azalışı ifade eden enflasyonun önemi, paranın ekonomilerdeki rolünden kaynaklanmaktadır. Paranın ekonomik faaliyetleri koordine etmekte oynadığı rol nedeniyle zaman içerisinde değerinde meydana gelen değişimler, hanehalklarının refahını etkilemektedir. Diğer yandan, enflasyon vergisinin asimetrik yansımaları önemli dağıtımsal etkiler yaratmaktadır. İktisadi şoklar veya hükümet politikalarında meydana gelen değişimler, genellikle gelir ve servetin yeniden dağılımı ile sonuçlanmakta; hatta bu yeniden dağılım süreci ılımlı enflasyon dönemlerinde bile gerçekleşebilmektedir. Dolayısıyla, enflasyonun dağıtımsal sonuçlarının ihmal edilmesi, enflasyonun ekonomideki etkilerinin değerlendirilmesinde yanıltıcı sonuçlar doğurabilmektedir (Erosa \& Ventura, 2002; Doepke \& Schneider, 2006).

Pek çok çalışma, enflasyonun borç alanlar-kredi sağlayıcılar, işçi-işveren, kamu sektörü-özel sektör arasındaki yeniden dağıtım etkilerini ele almıştır. Genellikle, enflasyonun düşük gelir gruplarının alım gücünü düşürdüğü, işsizlik oranlarını artırdığ1, finansal piyasalarda yüksek gelir gruplarından düşük gelir gruplarına doğru geliri yeniden dağıttığı kabul görmektedir (Blejer \& Guerrero, 1990; Chatterjee \& Corbae, 1992; Ribba, 2003; Meh et al., 2010). Ancak; enflasyon oranına, enflasyonun artış hızına ve eşik değerine, gelirin kaynağına, ülkelerin gelişmişlik düzeyine, kurumsal ve politik yapısına, vergi sistemlerine bağlı olarak söz konusu dağıtımsal etkiler farklılaşmaktadır (Romer \& Romer, 1998; Sun, 2011; Menna \& Tirelli, 2017; Galli \& van der Hoeven, 2001).

Çalışmamız, enflasyonun gelir eşitsizliği üzerindeki etkisini ortaya koymayı amaçlamaktadır. Bu çerçevede, 40 adet gelişmiş ve gelişmekte olan ülkenin yer aldığ örneklem grubuna yönelik olarak doğrusal model ile önce sabit etkili panel veri analizi gerçekleştirilecek; sonrasında enflasyon oranlarında meydana gelen değişimlerin ve 
başlangıç enflasyon oranının eşitsizlik seviyesini etkileyebileceği düşünüldüğünden panel eşik değer analizi ile enflasyon-gelir eşitsizliği ilişkisinin farklı rejimlerdeki yönü tespit edilecektir. Analizde, 1993-2019 dönemi için 40 adet gelişmiş ve gelişmekte olan ülkenin seçilmesinin nedeni bağımlı değişken olan gelir eşitsizliği göstergesine ilişkin veri kısıtıdır. Çalışmanın, enflasyonun doğrusal olmayan dağıtımsal etkileri ile ilişkili yerli ve yabancı literatürdeki az sayıdaki çalışmalardan birisi olması bakımından literatüre katkı sağlayacağı düşünülmektedir.

\section{Teorik Çerçeve}

Enflasyon, gelir gruplarını homojen olmayan biçimde ve farklı kanallardan etkilemektedir. Enflasyon; iş gücü gelirleri, sermaye gelirleri ve kamunun transfer ödemeleri üzerinden geliri yeniden dağıtmaktadır. Bu bağlamda, enflasyonun yüksek gelir gruplarına kıyasla düşük gelir gruplarını daha fazla olumsuz yönde etkilediği söylenebilmektedir (Fischer \& Modigliani, 1978; Monnin, 2014). Genellikle düşük gelir gruplarında yer alan hanehalklarının birçoğunun geliri iş gücü ücretlerine dayanmaktadır. Özellikle, pazarlık gücü düşük olan grupların varlığında, enflasyona endekslenmeyen ücretler erozyona uğramakta; enflasyon düşük gelir gelir gruplarının satın alma güçlerini azaltmaktadır (Kane \& Morisett, 1993). Enflasyonun, gelir eşitsizliğini etkilediği bir diğer kanal ise gelir gruplarının finansal varlıklara olan taleplerinin farklılaşmasıdır. Sturzenegger (1992)'ye göre enflasyona endekslenmiş finansal varlıklara ve yabancı para cinsinden araçlara erişim gelir düzeyi ile aynı yönde ilişkili olduğundan enflasyonist süreçlerde düşük gelir grupları nominal gelirlerini korumakta daha yetersiz kalmaktadır. Kamunun transfer ödemelerinin reel değerinin enflasyona bağlı olarak azalması ve söz konusu ödemelerin düşük gelir gruplarına yönelik olması nedeniyle de enflasyon gelir eşitsizliğini artırabilmektedir. Bununla birlikte, enflasyonun kamu gelirlerini aşındırması olarak tanımlanan Olivera- Tanzi etkisi ise örtük bir gelir transferine neden olabilmektedir. Bunun nedeni, vergi ödemelerinin tüm vergi mükellefleri için aynı gecikme sürelerine tabi olmamasıdır (Kane \& Morisett, 1993). Artan oranlı vergi sistemlerinin varlığı da enflasyonist süreçlerde gelir dağılımını bozucu etkilerin ortaya çıkmasına neden olabilmektedir. Enflasyonist dönemlerde, reel gelirlerinde artış gerçekleşmeyen hanehalklarının, bir üst vergi dilimine girerek daha yüksek oranda vergilendirilmesiyle sonuçlanan süreç gelir dağılımını olumsuz yönde etkileyebilmektedir (Sieroń, 2017).

Diğer yandan, beklenmeyen enflasyon gelir dağılımını düzeltici etkilere de neden olabilmektedir. Literatürde, "borçlu-alacaklı hipotezi" olarak ifade edilen yaklaşıma göre beklenmeyen enflasyon nominal yükümlülüklerin reel değerini azaltmakta ve borçlu ile alacaklı arasında geliri borçlu lehine yeniden dağıtmaktadır. Genellikle, borçlu kesimin düşük ve orta gelir gruplarından; alacaklı kesimin ise yüksek gelir gruplarından olduğundan hareketle enflasyonun gelir dağılımını iyileştirebileceği sonucuna ulaşılabilmektedir. Benzer koşullar, kamunun nominal yükümlülükleri için de geçerlidir (Meh \& Terajima, 2009).

Enflasyon ve gelir eşitsizliği arasındaki ilişki paranın nötr olmadığı varsayımına dayanan Cantillon Etkisi ile de açıklanmıştır. Buna göre para arzının artırılması enflasyonu 
Aktaş, E.E. \& S. Dokuzoğlu (2022), "Enflasyon-Gelir Eşitsizliği İlişkisi: Gelişmiş ve Gelişmekte Olan Ülkeler için Panel Eşik Değer Analizi”, Sosyoekonomi, 30(51), 449-470.

kademeli biçimde artırmakta; yeni paranın ilk alıcıları ve son alıcıları arasında gelirin yeniden dağıtımına neden olmaktadır. Yeni paranın piyasaya sürüldüğü süreçte fiyat artışları hemen gerçekleşmediğinden yeni paranın ilk alıcıları son alıcılarına göre daha avantajlı olmaktadır. Düşük gelir grupları yeni paranın son alıcıları olduğundan; yeni paraya ulaşmaktaki söz konusu zaman farkı geliri düşük gelir grupları aleyhine yeniden dağıtmaktadır (Sieroń, 2017).

\section{Ampirik Literatür}

Literatürde yer alan çalışmaların bir çoğu gelir eşitsizliğini etkileyen mali veya yarımali kanallar ile ilişkili iken; enflasyonun geliri yeniden dağıtıcı etkisinin konu edildiği çalışmalara da sıklıkla rastlanmaktadır. Nominal ücret katılıkları, yapışkan fiyatlar, ekonominin yapısal özellikleri, gelir ve servet kaynağındaki farklılıklar, gelişmişlik düzeyi, politik ve kurumsal yapı gibi değişkenler enflasyon - gelir eşitsizliği ilişkisinin ülkeler arasında farklılaşmasına neden olmaktadır.

Bach \& Ando (1957), enflasyonun gelirin yeniden dağıtımına ilişkin etkilerine dair çok az gösterge bulunduğunu; söz konusu etkinin ise karmaşık ve belirsiz süreçlerle ilişkili olduğunu ifade etmiştir. Nolan (1988), İngiltere için; Björklund (1991) ise İsveç için enflasyonun gelir eşitsizliği üzerinde anlamlı bir etkisinin bulunmadığı sonucuna ulaşmıştır. Benzer şekilde, Jäntti \& Jenkins (2010) 1961-1990 yıllarını kapsayan dönemde İngiltere için enflasyon ve işsizliğin gelir eşitsizliği üzerinde herhangi bir anlamlı etki yaratmadığı; Ang (2010) ise Hindistan için parasal istikrarsızlığın gelir eşitsizliği üzerinde herhangi bir negatif etkisinin bulunmadığ 1 sonucuna ulaşmıştır.

Diğer yandan, Wolff (1979) 1969-1975 yıllarını kapsayan dönemde Amerika'daki enflasyonist sürecin artan oranlı vergileme etkisi göstererek daha eşit bir servet dağılımına neden olduğu sonucuna ulaşmıştır. Achdut (1996) ile 1979-1993 yıllarını kapsayan dönemde İsrail için ortaya koyulan analizde gelir eşitsizliğindeki dalgalanmalar 2 ayrı dönemde ele almıştır. 1979-1984 yılları yüksek enflasyon dönemi iken 1985-1993 yılları fiyat istikrarı dönemi olarak analize konu edilmiştir. Fiyat istikrarı dönemi, yüksek işsizlik rakamları ile ilişkilendirilmiş ve bu dönemde gelir eşitsizliğinin arttığı sonucuna ulaşılmıştır. Ayrıca, çalışmada vergilerin enflasyonist dönemde geliri yeniden dağıtıcı etkisinin parasal istikrar döneminde zayıfladığı ortaya koyulmuştur. Mumtaz \& Theophilopoulou (2017) ile 19692012 yılları arasında İngiltere'de gelir eşitsizliğinde meydana gelen artışların para politikası şoklarıyla ilişkili olup olmadığı analiz edilmiştir. Çalışmada, para politikası şoklarının İngiltere'deki kazanç, gelir ve tüketim eşitsizliğini etkileyip etkilemediği ele alınmıştır. Yapısal Vektör Otoregresyon Modeli (SVAR) kullanılarak daraltıcı para politikası şoklarının kazanç, gelir ve tüketim eşitsizliğinde artışa yol açtığı sonucuna ulaşılmıştır. Zheng (2020) ise enflasyonun gelir eşitsizliği üzerindeki etkisini analiz etmek için heterojen haneleri menü maliyetleri yoluyla parasal bir Schumpeterci büyüme modeline dâhil etmiş; enflasyonun ekonomik büyümeyi ve gelir eşitsizliğini azalttığı sonucuna ulaşmıştır. 
Aktaş, E.E. \& S. Dokuzoğlu (2022), "Enflasyon-Gelir Eşitsizliği İlişkisi: Gelişmiş ve Gelișmekte Olan Ülkeler için Panel Eșik Değer Analizi”, Sosyoekonomi, 30(51), 449-470.

Bununla birlikte, Romer \& Romer (1998) ile 1970-1990 yıllarını kapsayan dönemde 76 ülke için ülkelerarası regresyon analizi gerçekleştirilmiş, enflasyonun gelir dağılımını kötüleştirdiği sonucuna ulaşılmıştır. Easterly \& Fischer (2001), 38 ülke için hanehalk1 verilerine dayanarak enflasyonun gelir eşitsizliğini artırdığı, düşük gelir gruplarının refahının enflasyonla doğrusal olmayan bir biçimde ters yönlü ilişkide olduğu sonucuna ulaşmıştır. Erosa \& Ventura (2002) ABD'de enflasyonun azalan oranlı bir vergi gibi etki yarattığını tespit ederek enflasyon vergisinin bireylerin tüketim düzeyine bağlı olması ve düşük gelirli larının varlıklarının daha büyük bir bölümünü nakit olarak tutmaları nedeniyle enflasyonun gelir eşitsizliğini artırdığını ortaya koymuştur. Albanesi (2007), enflasyon vergisinin asimetrik biçimde düşük gelir gruplarına yansımasını politik iktisat modelleri ile göstermiş, 51 gelişmiş ve gelişmekte olan ülke için 1966-1990 yıllarını kapsayan dönemde enflasyonun gelir eşitsizliğini artırdığı bulgusuna ulaşmıştır. Çalışmada, ortalama enflasyon oranı ile gelir eşitsizliği arasında gözlemlenen korelasyonun, maliye politikasının belirlenmesinin altında yatan bir dağıtım çatışmasının sonucu olarak gerçekleştiği ifade edilmektedir. Buna göre alt gelir gruplarının yüksek enflasyon dönemlerinde politik pazarlık gücü zayıflamakta, böylece gelir eşitsizliği artmaktadır. Thalassinos, Uğurlu \& Muratoğlu (2012) ise 2000-2009 yıllarını kapsayan dönemde 13 Avrupa ülkesi için enflasyon gelir eşitsizliği ilişkisini panel veri metodu ile analiz etmiş, gelir eşitsizliğinin belirleyicileri olarak istihdam düzeyi, büyüme oranı ve dışa açıklık değişkenlerini kontrol değişkeni olarak kullanmış ve enflasyonun gelir eşitsizliğini anlamlı ve pozitif yönde etkilediği hipotezini doğrulamıştır.

Enflasyon - gelir eşitsizliğine dair ilişki merkez bankası bağımsızlığı çerçevesinden de değerlendirilmiştir. Dolmas, Huffman, \& Wynne (2000) merkez bankasının bağımsız olmadığı ülkelerde geliri yeniden dağıtıcı kamu politikalarına yönelik politik baskıların; yüksek enflasyonist süreçlerle sonuçlanacağına işaret etmektedir. Buna göre bağımsız olmayan merkez bankalarının varlığında, yeniden dağıtıcı politikaların finansmanı para arzının kontrolsüz olarak artırılmasıyla gerçekleşmekte; böylece yeniden dağıtıcı kamu politikalarının neden olduğu enflasyon paradoksal biçimde gelir dağılımını daha da bozucu etkiler yaratmaktadir.

Literatürde, enflasyonun gelir eşitsizliği üzerindeki etkisinin başlangıç enflasyon oranına göre değişim gösterdiği çalışmalar da mevcuttur. Buna göre başlangıç enflasyon oranı yüksekse, enflasyonu düşürmek gelir eşitsizliğini azaltabilmekte; ancak düşük ise enflasyonu düşürmek daha yüksek eşitsizlik seviyesine neden olabilmektedir. Bu çerçevede, enflasyonun neden yalnızca düşük enflasyon oranlarına sahip ülkelere ilişkin zaman serisi analizlerinde gelir dağılımını iyileştirdiği; ancak çoğu ülkeler arası karşılaştırmalarda ve yüksek enflasyona sahip ülkelerin dâhil edildiği panel veri analizlerinde gelir dağılımını bozucu etkiler yarattığı açıklanabilmektedir (Galli \& van der Hoeven, 2001: 2). Bulíŕ (2001) fiyat istikrarının gelir dağılımı üzerindeki etkisinin doğrusal olmadığını ortaya koymuş, Kuznets (1955)'in gelir dağılımı ile ilişkili hipotezine enflasyonu da dâhil etmiştir. Buna göre 75 ülke için yapılan çalışmada, enflasyon gelir eşitsizliğini artırmakta ve söz konusu etki hiperenflasyonist ülkelerde daha güçlü gerçekleşmektedir. Çalışmada, \%5 oranında bir enflasyon eşiği tespit edilmiştir. Eşik değerin altında enflasyonda meydana gelen düşüş gelir 
eşitsizliğini artırmakta, eşik değerin üzerinde ise gelir eşitsizliğini azaltmaktadır. Galli \& van der Hoeven (2001), enflasyondaki bir artışın gelir eşitsizliğini hem azaltabileceğini hem artırabileceğini ve bunun büyük ölçüde başlangıçtaki enflasyon düzeyine bağlı olduğunu göstermiştir. Çalışmada, bu eşik değerin Amerika için \%6 olduğu sonucuna ulaşılmıştır. Monnin (2014), 10 OECD ülkesi için 1971-2010 yıllarını kapsayan döneme ilişkin panel veri analizi gerçekleştirmiş, uzun dönemde enflasyon ile gelir eşitsizliği arasında minimum eşik değer enflasyon oranı yaklaşık \%13 olan ve doğrusal olmayan bir ilişki tespit edilmiştir. Eşik enflasyon oranın altında enflasyon ile gelir eşitsizliği arasında ters yönlü bir ilişki, üzerinde ise aynı yönlü bir ilişki ampirik olarak doğrulanmıştır. Balcılar vd. (2018) ise gelir eşitsizliği ve enflasyon oranı arasındaki ilişkiyi değerlendirmek için 1976-2007 yıllarını kapsayan dönemde 50 Amerikan eyaleti için bir analiz gerçekleştirmiştir. Buna göre eşik bir enflasyon değerinin üzerinde, enflasyon ve gelir eşitsizliği arasında aynı yönlü ilişki, eşik değerin altında ise ters yönlü bir ilişki tespit edilmiştir. \%3 olarak tespit edilen eşik enflasyon oranı ile enflasyonun ekonomik büyüme, ücret geliri ve borçlu-alacaklı ilişkisi üzerindeki etkisi nedeniyle gelir dağılımını farklı yönde etkilediği gösterilmektedir.

\section{Veri ve Yöntem}

Çalışmada; 40 adet gelişmiş ve gelişmekte olan ülkenin ${ }^{1}$ 1993-2019 yılları arası yıllık verilerinden faydalanılmıştır. Ülkelerin seçimindeki en önemli zorluk veriye ilişkin kısıttır. Gini gelir eşitsizliği katsayısı, çalışmada tercih edilen Hansen (1999) panel eşik değer analizi çerçevesinde kayıpsız bir şekilde elde edilmek zorundadır. Diğer tüm değişkenlerin de dengeli panel oluşturulması bakımından eksiksiz elde edilmesi gerekmektedir. Gelir eşitsizliği katsayıları ile ilişkili zorluk güncel, güvenilir ve kayıpsız göstergelere ulaşamamaktan kaynaklanmaktadır. Standardize Edilmiş Dünya Gelir Eşitsizliği Veritabanından (Version 9.1) elde edilen gelir eşitsizliği katsayısı 0 (en düşük eşitsizlik katsayısı) ile 100 (en yüksek eşitsizlik katsayısı) arasında değer almaktadır (Solt, 2020: 1184-1186). Vergi ve transferler sonrası hanehalkı harcanabilir gelirinin göstergesi olan gelir eşitsizliği katsayısı, modelde kullanılan bağımlı değişkeni göstermektedir. Sağlamlık kontrolu için vergi ve transferler öncesi hanehalkı harcanabilir gelirinin göstergesi olan gelir eşitsizliği katsayısı da analize dâhil edilmiştir. Enflasyon değişkeni, eşik değişken olarak tanımlanmıştır ve değişken Dünya Bankası Veritabanı'ndan elde edilmiştir. Enflasyon değişkeni tüketici fiyatları cinsinden $(2010=100)$ regresyona dâhil edilmiştir. Verilere ilişkin özet bir bilgi niteliğindeki Tablo 1'de değişkenler, göstergeler ve değişkenlerin elde edildiği kaynaklar yer almaktadır. Kontrol değişkenler de Dünya Bankası Veritabanından elde edilmiştir. Kontrol değişkenlere ilişkin özet bilgi de Tablo 1'de yer almaktadır. Bu değişkenler $\underline{\text { ISSIZLIK }}, \underline{\text { ACIKLIK }}, \underline{\text { TUKETIM }}, \underline{B U Y U M E}$ ve $\underline{\text { YATIRIM }}$ değişkenleridir.

1 Ermenistan, Belçika, Brezilya, Bulgaristan, Kanada, Çin, Kolombiya, Kosta Rika, Danimarka, Dominik Cumhuriyeti, El Salvador, Estonya, Finlandiya, Gürcistan, Honduras, Macaristan, Endonezya, Italya, Irlanda, Kazakistan, Kirgızistan, Malezya, Moldova, Hollanda, Norveç, Panama, Paraguay, Peru, Polonya, Romanya, Rusya, Singapur, Tayland, Türkiye, Ukrayna, Birleşik Krallık, Amerika Birleşik Devletleri, Uruguay, Vietnam, Ekvator. 
Değişkenler, enflasyon-eşitsizlik ilişkisi açısından önemli etkilere sahip olduğu öngörülen göstergeler arasından önceki literatür (Balcilar vd. 2018) ile uyumlu olarak tercih edilmiştir.

Tablo: 1

\section{Veriye İlişkin Bilgi}

\begin{tabular}{|c|c|c|}
\hline Değişken & Gösterge & Kaynak \\
\hline $\begin{array}{l}\text { Bağımlı Değişken: } G I N I \_N E T \text { ve } \\
\text { GINI MKT (Sağlamlık kontrolü için) }\end{array}$ & $\begin{array}{l}\text { Vergi ve transferler öncesi ve sonrası hanehalkı geliri ile } \\
\text { denkleştirilmiş gelir eşitsizliği göstergesi }\end{array}$ & $\begin{array}{l}\text { Frederick Solt Standardize Edilmiş } \\
\text { Dünya Gelir Eşitsizliği Veritabanı }\end{array}$ \\
\hline Eşik Değişken: ENFLASYON & Tüketici Fiyatları Endeksi (TÜFE) $2010=100$ & Dünya Bankası Veritabanı \\
\hline \multicolumn{3}{|c|}{ Kontrol Değișkenler } \\
\hline$\underline{I S S I Z L I K}$ & $\begin{array}{l}\text { İşgücünün toplam yüzdesi cinsinden toplam işsizlik oranı } \\
\text { (Uluslararası Çalışma Örgütü yöntemine göre) }\end{array}$ & Dünya Bankası Veritabanı \\
\hline$\underline{A C I K L I K}$ & $\begin{array}{l}\text { GSYH yüzdesi olarak mal ve hizmetlerin ihracat ve ithalat } \\
\text { toplamı }\end{array}$ & Dünya Bankası Veritabanı \\
\hline$\underline{\text { TUKETIM }}$ & cari fiyatlarla (\$) hükümetin nihai tüketim harcamaları & Dünya Bankası Veritabanı \\
\hline$\underline{B U Y U M E}$ & cari fiyatlarla (\$) kişi başına düşen gayri safi yurtiçi hâsıla & Dünya Bankası Veritabanı \\
\hline YATIRIM & cari fiyatlarla (\$) gayri safi sabit sermaye oluşumu & Dünya Bankası Veritabanı \\
\hline
\end{tabular}

Tablo 2'den de görülebileceği gibi Gini katsayısı ölçümleri ülkeler arasında çok fazla farklılık göstermemektedir. Eşik değişken olan ve tüketici fiyatları cinsinde tanımlanan enflasyon değişkeni ise ülkeler arasında önemli ölçüde farklılaşmaktadır. Kontrol değişkenlerden $\underline{B U Y U M E}$ ve $\underline{A C I K L I K}$ değişkeni hariç değişkenlerin ülkeler özelinde birbirine yakın seyrettiği; serilerin standart sapmalarının ve ortalamalarının da ihmal edilebilir düzeyde farklılaştığı görülmektedir.

Tablo: 2

Tanımlayıcı İstatistikler

\begin{tabular}{|c|c|c|c|c|c|}
\hline Değişken & Gözlem & Ortalama & Standart Sapma & Minimum Değer & Maksimum Değer \\
\hline GINI NET & 1080 & 37,01 & 8,23 & 21,90 & 54,30 \\
\hline$\overline{G I N I \_M K T}$ & 1080 & 46,16 & 6,53 & 21,90 & 63,20 \\
\hline$\overline{E N F L A S Y O N}$ & 1080 & 84,97 & 36,71 & 0,20 & 281,659 \\
\hline ISSIZLIK & 1080 & 7,11 & 3,69 & 0,21 & 20,71 \\
\hline$\overline{A C I K L I K}$ & 1080 & 91,88 & 59,50 & 15,63 & 437,32 \\
\hline BUYUME & 1080 & 15018,65 & 18789,25 & 182,30 & 102913,00 \\
\hline YATIRIM & 1080 & $1,91 \mathrm{e}+11$ & $6,40 \mathrm{e}+11$ & $6,70 \mathrm{e}+07$ & $6,10 \mathrm{e}+12$ \\
\hline TUKETIM & 1080 & $1,29 \mathrm{e}+11$ & $3,73 \mathrm{e}+11$ & $1,50 \mathrm{e}+08$ & $3,00 \mathrm{e}+12$ \\
\hline
\end{tabular}

\subsection{Doğrusal Sabit Etkili Model}

Sabit etkili panel veri modelleri birim etkilerinin, başka bir ifade ile birimler arası farklılıkların sabit olduğu durumlarda kullanılmaktadır. Bu etki, tahmin sonuçları içerisinde sabit parametre ile ifade edilmektedir. Gözlemlenemeyen birim etkilerinin modelde yer alan açıklayıcı değişkenlerle ilişkili olduğu sabit etkili panel veri modellerinde eğim parametreleri tüm birimler için aynı olsa da sabit panel birimlere göre değişmektedir. Birim etkilerinin analiz edildiği regresyon sabiti deterministik olmamakla birlikte örnek birimlerin üzerine yoğunlaşıldığı gözlemlenmektedir. Örnek birimlerin büyük bir anakütleden gelmediği durumlarda bu modeller kovaryans modelleri olarak tanımlanmaktadır. Belirli bir $N$ sayıdaki panel birim tahminlere konu olmaktadır (Ün, 2018: 60).

$$
\begin{aligned}
& Y_{i t}=\alpha_{i t}+\beta_{2 i t} X_{2 i t}+\beta_{k i t} X_{k i t}+U_{i t} \\
& \alpha_{i t}=\alpha_{i} \text { tüm t'ler için }
\end{aligned}
$$




$$
\beta_{\text {kit }}=\beta_{k} \text { tüm i ve t'ler için }(\mathrm{k}=2,3, \ldots, \mathrm{K})
$$

Birimlere göre meydana gelen farklılıkların eğim katsayılarını etkilediği durumlar için sabit katsayılı modeller kullanılmaktadır (Ün, 2018: 60).

$$
\alpha_{k i t}=\alpha_{k i} \text { tüm i'ler için } \mathrm{J}=1, \ldots . \mathrm{N} ; \mathrm{t}=1, \ldots . \mathrm{T} ; \mathrm{k}=1, \ldots . \mathrm{k}
$$

Sabit etkili modellerde bağımsız değişkenlerin hata terimi bileşenleri ile ilişkisiz olduğu varsayımı bulunmamaktadır. Tesadüfi etkili modellerde ise hata terimi bileşenleri ile modeldeki bağımsız değişkenlerin ilişkisiz olduğu varsayılmaktadır. Sabit etkili model ile tesadüfi etkili modelin kullanılması konusunda bir önbilgi var ise buradan hareketle tahminler gerçekleştirilebilir. Enflasyonun gelir eşitsizliği üzerindeki eşik etkisinin tahmin edildiği çalışmada bu önbilginin varlığını ihtiva eden Hansen (1999) analizi kullanılmaktadır. Öte yandan, sabit etkili modeller serilerde içsellik, değişen varyans, otokorelasyon ve yatay kesit bağımlılığı olup olmamasına bağlı olarak farklı tahmincilerin kullanılabileceğini önermektedir. Çalışmada, Hansen (1999) yaklaşımı sözü edilen durumları bertaraf eden bir analiz olması ve yöntemsel üstünlük sağlaması sebebiyle tercih edilmiştir. İlişkinin doğrusal olup olmadığının test edildiği çalışmada Hansen (1999) eşik analizinden önce doğrusal model ile öntahmin niteliğinde bulgulara ulaşılması hedeflenmiştir.

\subsection{Tek Eşikli Model}

Hansen (1999) eşik regresyon modellerinin tahminini sağlayacak bir asimptotik dağılım teorisi sunmaktadır. Önyükleme (bootstrap) yöntemi kullanarak geleneksel yöntemlerden farklılaşmaktadır ve eşik regresyon modellerinin tahmin edilmesine olanak tanımaktadır. Bir örneklemdeki tüm gözlemler içerisinde regresyona ilişkin fonksiyonların aynı mı, yoksa ayrık mı olduklarını belirlemek için yöntem geliştirmiştir. Bireysel gözlemlerin gözlemlenen bir değişkenin değerine göre ayrı rejimlerde değerlendirilip değerlendirilemeyeceği eşik regresyon modelleri ile tespit edilmektedir. Hansen (1999) ekonometrik tekniklerin eşik regresyonu için yöntemsel algılarının avantajına karşın etkili sonuçlar ortaya koymadığını iddia etmektedir. Eşik regresyonu için panel veriler ile etkili ekonometrik teknikleri kullanmaktadır. Bir asimptotik dağılım teorisi geliştirdiği çalışmasında seriler için güven aralıkları oluşturmuş̧ur. Bootstrap (önyükleme) yöntemini de eşik etkisinin istatistiksel değerini ifade etmek için kullanmaktadır. Eşik etkinin test edilebilmesi için iki aşamalı sıradan en küçük kareler yaklaşımından faydalanılmaktadır. Bunu yaparken ilk olarak her bir olası eşik değer için hata kareleri toplamının birbirinden bağımsız olarak hesaplandığı, sonra ise ilgili bu değerlerin minimize edildiği bir yöntem kullanılmaktadır. Nihayetinde, eşik parametresi tarafından belirlenen ayrı rejimlerde katsayı parametreleri tahmin edilmektedir (Hansen, 1999: 345-346). Hansen (1999) çoklu doğrusallık ve endojenite gibi sorunların çözümünde metodolojik üstünlük sağlayan bir yöntem olarak eşik değer analizlerinde son zamanlarda yaygın olarak kullanılmaktadır. Tanı testleri bakımından Hansen (1999) çalışmasında kısıtlara işaret etmekte olup gelecek çalışmaların heteroskedastisite (değişen varyans), bağımlı değişkenin gecikmeli değeri, 
tesadüfü etkiler vb. unsurların gelecek çalışmalar açısından dikkate alınmasını önermektedir. Nitekim, dinamik panel eşik modelleri de bu çerçevede kullanılmaktadır. Ancak, mevcut istatistiki ve ekonometrik paket programlar vasıtası ile tanı testleri için yeterli destek sağlanamamaktadır ve testlerin manuel olarak çalıştırılması gerektiği düşünülmektedir. Bu çalışma ise sabit etkiler panel eşik analizini merkeze almaktadır. Hansen (1999) tek eşikli modeli şu şekilde belirtmektedir (Hansen, 1999: 347; Wang, 2015: 122):

$$
y_{i t}=\mu+X_{i t}\left(q_{i t}<\gamma\right) \beta_{1}+X_{i t}\left(q_{i t} \geq \gamma\right) \beta_{2}+u_{i}+e_{i t}
$$

Burada $q_{i t}$ eşik değişkendir. $\gamma$ ise eşitliği $\beta_{1}$ ve $\beta_{2}$ olmak üzere iki rejime ayıran eşik parametresidir. $u_{i}$ ve $e_{i t}$ sirasıyla bireysel etkileri ve hata terimini göstermektedir. (2) nolu denklemi aşağıda şekilde göstermek de mümkündür. $I$ gösterge fonksiyonunu temsil etmektedir (Hansen, 1999: 347; Wang, 2015: 122):

$$
\begin{aligned}
& y_{i t}=\mu+X_{i t}\left(q_{i t}, \gamma\right) \beta+u_{i}+e_{i t} \\
& X_{i t}\left(q_{i t}, \gamma\right)=\left\{\begin{array}{l}
X_{i t} I\left(q_{i t}<\gamma\right) \\
X_{i t} I\left(q_{i t} \geq \gamma\right)
\end{array}\right\}
\end{aligned}
$$

$\gamma$ eşik parametresi veri iken $\beta$ 'nin en küçük sıradan kareler tahmincisi (4) nolu denklemdeki gibidir (Hansen, 1999: 349; Wang, 2015: 122):

$$
\hat{\beta}=\left\{X^{*}(\gamma)^{\prime} X^{*}(\gamma)\right\}^{-1}\left\{X^{*}(\gamma)^{\prime} y^{*}\right\}
$$

$y^{*}$ ve $X^{*}$ grup içi sapmalardır. Artık kareler toplamı $\hat{e}^{* \prime}$ ve $\hat{e}^{*}$ dir. $\gamma$ eşik parametresini tahmin etmek için $q_{i t}$ eşik değişkenin alt kümesinin hesaplanması gerekmektedir. Tüm örneklemi test etmek yerine seri, $(\underline{\gamma}, \bar{\gamma})$ aralığında sınırlandırılmaktadır. Bu aralıklar $q_{i t}$ eşik değişkenin dağılımıdır. $\gamma$ 'nin tahmincisi artık kareler toplamını minimize eden değerdir ve (5) nolu denklemdeki gibidir (Hansen, 1999: 349; Wang, 2015: 122):

$$
\begin{aligned}
& \hat{\gamma}=\arg \min S_{1} \gamma \\
& \gamma
\end{aligned}
$$

$\gamma$ hesaplanıyorsa, model siradan doğrusal modelden farklı değildir. Ancak, hesaplanamıyorsa $\gamma$ tahmincisinin dağılımını standart dışı yapan rahatsız edici bir parametre (nuisance parameter) problemi vardır. Hansen (1999) $\hat{\gamma}$ 'nin $\gamma$ için tutarlı bir tahminci olduğunu kanıtlamıştır. $\gamma=\gamma_{0}$ ' 1 test etmenin en iyi yolunun en çok olabilirlik oranı $(L R)$ ile "reddedilmeyen bölge" yönteminin kullanılarak güven aralığı oluşturmak olduğunu savunmuştur ve bu istatistik şu şekildedir (Hansen, 1999: 351; Wang, 2015: 122):

$$
\begin{aligned}
& L R_{1}(\gamma)=\frac{\left\{L R_{1}(\gamma)-L R_{1}(\hat{\gamma})\right\}}{\widehat{\sigma}^{2}} \stackrel{P r}{\rightarrow} \xi \\
& \operatorname{Pr}(\mathfrak{x}<\xi)=\left(1-e^{\frac{-x}{2}}\right)^{2}
\end{aligned}
$$


Güven aralığı $\alpha$ veri iken alt sınır, $L R$ serisindeki maksimum değere karşılık gelir ve bu değer $\alpha$ dağılımından daha küçüktür. Üst sınır ise $L R$ serisindeki $\alpha$ dağılımından daha küçük olan minimum değere karşılık gelir. $\alpha$ dağılımı (7) nolu denklemin aşağıdaki ters fonksiyonundan hesaplanmaktadır (Hansen, 1999: 352; Wang, 2015: 123):

$$
c=-2 \log (1-\sqrt{1-\alpha})
$$

Şöyle ki, 0.1, 0.05 ve 0.01 güven aralıkları için üç adet kritik değer hesaplanmaktadır. Eğer en çok olabilirlik oranı $L R_{1}\left(\gamma_{0}\right)$ dağılımın kritik değerleri $c(\alpha)$ 'dan büyük ise boş hipotez reddedilmektedir. Bir eşik etkisinin test edilmesi, katsayıların her rejimde aynı olup olmadığının test edilmesiyle aynıdır. Boş hipotez ve alternatif hipotez (doğrusal ve tek eşikli model) (8) nolu eşitlikteki gibidir (Hansen, 1999: 351; Wang, 2015: 123):

$$
H_{0}: \beta_{1}=\beta_{2} H_{\alpha}: \beta_{1} \neq \beta_{2}
$$

$F$ istatistiği ise (9) nolu eşitlikteki gibidir (Hansen, 1999: 350; Wang, 2015: 123):

$$
F_{1}=\frac{S_{0}-S_{1}}{\widehat{\sigma}^{2}}
$$

Boş hipotezin $\left(H_{0}\right)$ geçerliliği durumunda, $\gamma$ eşik parametresi belirlenememektedir ve $F_{1}$ istatistiği standart olmayan asimptotik bir dağılım göstermektedir. Bu sebeple, eşik etkisinin anlamlılığının test edilmesi bakımından $F$ istatistiğinin kritik değerleri için önyükleme (bootsrap) yöntemi kullanılmaktadır. $F$ istatistiği testinin p-değeri anlamlılık düzeyi, eşik etkisinin anlamlı olup olmadığını belirtmektedir. Eğer anlamlı bir eşik test edilmiş ise $F$ istatistik değerinin, dağılımın kritik değerleri $\alpha$ 'nın güven aralıkları için tahmin edilen katsayılardan büyük olduğu gözlemlenmektedir.

\section{3. Çok Eşikli Model}

Hansen (1999) çok eşikli modeller için de tahmin yapılmasına olanak tanımaktadır. Çift eşikli örnek bir model şu şekildedir (Hansen, 1999: 353; Wang, 2015: 123):

$$
y_{i t}=\mu+X_{i t}\left(q_{i t}<\gamma_{1}\right) \beta_{1}+X_{i t}\left(\gamma_{1} \leq q_{i t}<\gamma_{2}\right) \beta_{2}+X_{i t}\left(q_{i t} \geq \gamma_{2}\right) \beta_{3}+u_{i}+e_{i t}
$$

$\gamma_{1}$ ve $\gamma_{2}$ eşik parametreleri olup eşitliği $\beta_{1}, \beta_{2}$ ve $\beta_{3}$ olmak üzere üç ayrı rejime ayırmaktadır. Pek fazla kullanılmayan grid aralığı (grid interval) yöntemi kullanılarak eşitliğin $(N \times T)^{2}$ defa hesaplanması gerekmektedir. Bai (1997) ve Bai ve Perron'a (1998) göre ardışık tahminci tutarlıdır; bu nedenle eşikler aşağıdaki gibi tahmin edilmektedir (Hansen, 1999: 353; Wang, 2015: 123):

$$
\begin{aligned}
& \gamma_{2}^{r r}=\arg \min S_{2}^{r}\left(\gamma_{2}\right) \\
& S_{2}^{r}=S\left\{\min \left(\hat{\gamma}_{1}, \gamma_{2}\right) \max \left(\hat{\gamma}_{1}, \gamma_{2}\right)\right\} \\
& \operatorname{LR}_{2}^{r}\left(\gamma_{2}\right)=\frac{\left\{S_{2}^{r}\left(\gamma_{2}\right)-S_{2}^{r}\left(\hat{\gamma}_{2}^{r}\right)\right\}}{\sigma_{22}^{\wedge}}
\end{aligned}
$$




$$
\begin{aligned}
& \gamma_{1}^{r}=\arg \min \left\{S_{1}^{r}\left(\gamma_{1}\right)\right\} \\
& S_{1}^{r}=S\left\{\min \left(\hat{\gamma}_{1}, \gamma_{2}\right) \max \left(\hat{\gamma}_{1}, \gamma_{2}\right)\right\} \\
& L R_{1}^{r}\left(\gamma_{1}\right)=\frac{\left\{S_{1}^{r}\left(\gamma_{1}\right)-S_{1}^{r}\left(\hat{\gamma}_{1}^{r}\right)\right\}}{\sigma_{21}^{2}}
\end{aligned}
$$

Eşik etkisi testi de ardışıktır; yani tek eşikli bir modelde sıfır hipotezi reddedilirse, çift eşikli model de test edilmelidir. Boş hipotez, tek eşikli bir modeldir ve alternatif hipotez, çift eşikli bir modeldir. $F$ istatistiği ise şu şekilde oluşturulmaktadır (Hansen, 1999: 354; Wang, 2015: 124):

$$
F_{2}=\frac{\left\{S_{1}^{r}\left(\gamma_{1}\right)-S_{1}^{r}\left(\widehat{\gamma}_{1}^{r}\right)\right\}}{\sigma_{22}^{2}}
$$

Tek eşikli modelde olduğu gibi bootstrap (önyükleme) yöntemi kullanılmaktadır. Boş hipotez veri iken $H_{0} D G P, X_{i t}^{*} \beta_{S}+v_{i t}^{*}$ şeklinde yeni bir seri oluşturulmaktadır. $\beta_{S}, H_{a} D G P$ veri iken tek eşikli modelin bir tahmincisidir. İkiden fazla eşik parametresine sahip modeller için de işlem benzerdir. Chan (1993) ve Hansen (1999), $\beta$ (eğim parametresi) sonucunun ve tahminin güvenilirliğinin eşik tahminine bağımlılığının birinci dereceden asimptotik öneme sahip olmadığını, dolayısıyla $\beta$ (eğim parametresi) tahminine $\gamma$ veri olduğu için devam edilebileceğini ifade etmektedir (Hansen, 1999: 354-355; Wang, 2015: 124).

Bu çalışmanın verilerini ve amacını Hansen (1999) çerçevesinde değerlendirmek mümkün olup model, enflasyonun gelir eşitsizliği etkilerinin analizinde, içsel şekilde alt gruplara ayrılan örneklemin eşik değerlerinin tespitine yardımcı olmaktadır. Eşik değere bağlı olarak farklı yönlerde ilişki açıklanabilmektedir. (2) ve (10) nolu denklemlerden elde edilen model, dengeli panel veri seti ile oluşturulmuştur. Modelde $t$ zaman etkilerini $i$ bireysel etkileri temsil etmektedir. $G I N I_{i t}$ vergi ve transferler sonrası hanehalkı harcanabilir gelirinin temsili olan gelir eşitsizliği göstergesini, ENFLASYON $N_{i t}$ tüketici fiyatları endeksi ile temsil edilen enflasyon göstergesi olan açıklayıcı değişkeni göstermektedir. $X_{i t}$ ise yine beşeri, demografik, kurumsal, makro ve mali göstergeleri içeren kontrol değişkenler vektörünü belirtmektedir. Enflasyonun gelir eşitsizliğinin tahmininde kullanılan temel model (14) nolu denklemdeki gibidir:

$$
\text { GINI }_{i t}=\left\{\begin{array}{c}
\delta_{i}+\alpha_{1} X_{i t}+\beta_{1} \text { ENFLASYON }_{i t}+e_{i t}, \text { ENFLASYON }_{i t} \leq \lambda \\
\delta_{i}+\alpha_{2} X_{i t}+\beta_{2} \text { InENFLASYON }_{i t}+e_{i t}, \text { ENFLASYON }_{i t}>\lambda
\end{array}\right.
$$

$e_{i t}$ sonsuz varyans ve sıfir ortalama ile özdeş ve bağımsız dağıldığı varsayılan hata terimini göstermektedir. ENFLASYON olup $\delta_{i}$ farklı enflasyon oranlarına sahip panel ülkelerinin heterojen yapısını gösteren sabit etkileri içermektedir. $\lambda$ şik değer tahminini temsil etmektedir. $\beta_{1}, \beta_{2}$ enflasyonun farklı rejimlerde, başka bir deyişle tahmin edilen eşik değerin altında ve üstünde farklılaşan gelir eşitsizliği etkilerini ortaya çıkarmaktadır.

Buraya kadar yapılan açıklamalardan hareketle ilişkinin boş hipotezini enflasyon gelir eşitsizliği ilişkisi doğrusaldır; alternatif hipotezi ise enflasyon gelir eşitsizliği ilişkisi 
doğrusal değildir ve anlamlı (tek) eşik etkisi tespit edilmektedir şeklinde ifade etmek mümkündür. Model kısmında da belirtildiği üzere, eşik değer etki testi (threshold effect test) olasılık değerinin anlamlılığına ve $F$ istatistik katsayısının güven aralıkları için tahmin edilen kritk değerlerin katsayıdan büyük olup olmamasına bağlı olarak tahmin edilen eşik değer, söz konusu ilişkinin öncelikle doğrusallığını, sonrasında eşiğin altında ve üzerinde yönünü tayin etmektedir. Bununla birlikte tek eşik tahminini takiben çok eşikli tahmin de analize dâhil edilmiştir. Hansen (1999) panel sabit etkili eşik analizinin, 40 adet gelişmiş ve gelişmekte olan ülke grubu özelinde enflasyon gelir eşitsizliği ilişkisine dair etkili ve güvenilir bulgular ortaya koyabileceği varsayılmaktadır. Doğrusal olmayan ilişkilerin tahmininde kullanılan bir yöntem ile görece heterojen yapıdaki panel ülkelerin tahminine olanak tanıyan analizin literatüre katkı sağlayacağı öngörülmektedir.

\section{Bulgular ve Tartışma}

İlk olarak, doğrusal model ile sabit etkili panel veri analizi gerçekleştirilmiştir. Tahminlere ilişkin bulgular Tablo 3'de paylaşılmaktadır. Bağımlı değişken olarak tanımlanan her iki gelir eşitsizliği göstergesinin diğer değişkenler ile ilişkisi, bir değişken $(\underline{\text { YATIRIM }})$ hâriç istatistiki olarak anlamlıdır. Bununla birlikte, anlamlı ya da anlamsız tüm değişkenlerin etkilerinin yönü (pozitif ve negatif) beklentiler ile literatüre uygun ve öngörülebilirdir. Ang (2010), Shahbaz ve Islam (2011), Jalil (2012), Shahbaz, Loganathan, Tiwari ve Sherafatian-Jahromi (2015), Franco ve Gerussi (2013), Gülmez ve Altıntaş (2015), Park (2015), Argun (2016) ve Topuz ve Dağdemir (2016) gibi literatür örnekleri doğrusal zaman ve panel seri analizleri ile enflasyon ile gelir eşitsizliği arasında negatif ilişki tespit etmişlerdir. ( $\underline{I S S I Z L I K})$ ve ( $\underline{B U Y U M E})$ değişkenlerinin gelir eşitsizliği ile ilişkisi pozitif, kamunun nihai tüketim harcamaları olarak tanımlanan ( $\underline{\text { TUKETIM }})$ ile ( $\underline{\text { YATIRIM }})$ ve $(A C I K L I K)$ değişkenlerinin gelir eşitsizliği ile ilişkisi negatiftir. (GINI_MKT) değişkeni ile yapılan sağlamlık kontrolü bulguları da tüm değişkenler için benzer katsayıları, anlamlılık seviyelerini, ilişki yönünü tespit etmektedir.

Tablo: 3

Doğrusal Model Tahmin Bulguları

\begin{tabular}{|c|c|c|c|}
\hline \multicolumn{4}{|c|}{ Bağımlı değişken: $G I N I$ NET } \\
\hline Değișken & Katsayı (standard sapma) & Anlamlılık & Etkinin işareti \\
\hline ENFLASYON & $-0,0176(0,0025)$ & $\sqrt{ }(0,000)$ & $(-)$ \\
\hline ISSIZLIK & $0,1665(0,0235)$ & $\sqrt{(0,000)}$ & $(+)$ \\
\hline$\overline{\text { ACIKLIK }}$ & $-0,0202(0,0029)$ & $\sqrt{(0,000)}$ & $(+)$ \\
\hline$\overline{T U K E T I M}$ & $-1,4462(0,3153)$ & $\sqrt{ }(0,000)$ & $(-)$ \\
\hline BUYUME & $1,5872(0,4483)$ & $\sqrt{ }(0,000)$ & $(+)$ \\
\hline YATIRIM & $-0,2657(0,2777)$ & $\mathrm{X}(0,339)$ & $(+)$ \\
\hline \multicolumn{4}{|c|}{ Bağımlı Değișken: $\boldsymbol{G I N I} \boldsymbol{M K T}$} \\
\hline ENFLASYON & $-0,0189(0,0026)$ & $\sqrt{ }(0,000)$ & $(-)$ \\
\hline ISSIZLIK & $0,2107(0,0245)$ & $\sqrt{ }(0,000)$ & $(+)$ \\
\hline$\overline{\text { ACIKLIK }}$ & $-0,0279(0,0030)$ & $\sqrt{ }(0,000)$ & $(+)$ \\
\hline$\overline{T U K E T I M}$ & $-1,4975(0,3280)$ & $\sqrt{(0,000)}$ & $(-)$ \\
\hline BUYUME & $1,9424(0,4663)$ & $\sqrt{(0,000)}$ & $(+)$ \\
\hline YATIRIM & $-0,2658(0,2889)$ & $\mathrm{X}(0,358)$ & $(+)$ \\
\hline
\end{tabular}

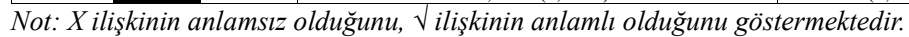


Yalnızca doğrusal bir analiz ile böylesi değerlendirmeler yapmak oldukça eksik ve dahası yanlış olacaktır. Nitekim, enflasyon değişkeninin gelir eşitsizliği ile anlamsız ilişkisi, başka modellemeler ile ilişkinin test edilmesini zorunlu kılmaktadır. Enflasyon oranlarının farklılaşmasının (azalmasının ya da artmasının) eşitsizlik seviyesini de etkileyebileceği düşünülmektedir. Bu sebeple, enflasyon değişkeni üzerinden tanımlanabilecek bir eşik ile ilişkinin farklı rejimlerdeki yönünü tespit etmek önem arz etmektedir. 40 adet gelişmiş ve gelişmekte olan ülkedeki enflasyon gelir eşitsizliği arasındaki panel eşik en küçük kareler yöntemi ile tahmin edilen ilişkiye ait (2) nolu denkleme ilişkin tek eşikli etki test sonuçları Tablo 4'den görülebilmektedir.

Tablo: 4

\section{Tek Eşikli Etki Test Sonuçları}

\begin{tabular}{|c|c|c|c|c|c|}
\hline \multirow{2}{*}{ Eşik değer } & \multirow{2}{*}{$\boldsymbol{F}$ istatistiği } & \multirow{2}{*}{$\boldsymbol{p}$ değeri } & \multicolumn{3}{|c|}{ Kritik değerler } \\
\cline { 4 - 6 } & & $\sqrt{ } \mathbf{0 1 0}$ & $\mathbf{\% 5}$ & $\mathbf{\% 1}$ \\
\hline 49,300 & 188,85 & $\sqrt{0}, 003^{*}$ & 91,243 & 113,821 & 144,232 \\
\hline
\end{tabular}

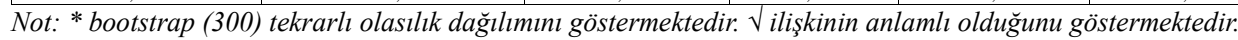

Tüketici fiyatları endeksi cinsinden tanımlanan enflasyon değişkenine ilişkin eşik değer 49,300 olup $p$ değeri (0,003)'dür. $F$ istatistiği katsayısı olan $(188,85)$ değerinden de görülebileceği üzere $\% 10, \% 5$ ve \%1'lik tüm kritik değerler bu değerden küçüktür. Bu itibarla, boş hipotez $\% 1$ düzeyinde reddedilmektedir. Bir başka ifadeyle, enflasyon ve gelir eşitsizliği arasında doğrusal bir ilişki bulunmamaktadır ve bu ilişki güçlü anlamlı eşik etkisine sahiptir. Enflasyon değişkenine Hansen (1999)'un önerdiği şekliyle çoklu eşik analizi de uygulanmıştır. (10) nolu denklemdeki model ile yapılan test sonuçları, üç ayrı eşik değer parametresi, bu parametrelere ilişkin olasılık değeri, $F$ istatistiği ile kritik değerleri Tablo 5'de yer almaktadır.

Tablo: 5

Çok Eşikli Etki Test Sonuçları

\begin{tabular}{|c|c|c|c|c|c|}
\hline \multirow{2}{*}{ Eşik değer } & \multirow{F}{*}{$\boldsymbol{F}$ istatistiği } & \multirow{2}{*}{ değeri } & \multicolumn{3}{|c|}{ Kritik değerler } \\
\cline { 4 - 6 } & & & $\mathbf{\% 1 0}$ & $\mathbf{\% 5}$ & $\mathbf{\% 1}$ \\
\hline 49,300 & 188,85 & $\sqrt{ } 0,003 *$ & 91,243 & 113,821 & 144,232 \\
\hline 45,000 & 129,93 & $\sqrt{ } 0,010^{*}$ & 83,793 & 100,555 & 121,909 \\
\hline 24,800 & 46,53 & $X 0,666^{*}$ & 125,097 & 141,026 & 187,632 \\
\hline
\end{tabular}

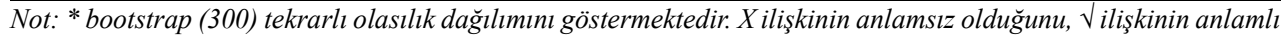
olduğunu göstermektedir.

İkinci eşik değer parametresi $F$ istatistik katsayısı $(129,93)$, dağılımın güven aralıkları tarafından belirlenen kritk değer katsayılarından büyüktür ve olasılık değerlei de anlamslıdır. $(0,010)$ Bu bulgular, modelde çift eşikli etkinin olduğunu, ama üç eşikli etkinin olmadığını göstermektedir. Zira, üçüncü eşiğin olasılık değeri $(0,666)$ 'dır. $(46,53)$ olan $F$ istatistik katsayısı tüm kritik değerlerden küçüktür. Tek ve çift eşik değeri $(49,300)$ ve $(45,000)$ üzerinden yapılan enflasyon oranı tahmin bulgusuna göre enflasyon oranının bu iki seviyeden sonra gelir eşitsizliği üzerinde bir rejim değişikliğine sebep olduğunu söylemek gerekmektedir. Ek-1'de (GINI_MKT) göstergesi ile yapılan tek ve çok eşikli etki test sonuçları da gösterilmektedir. Bu bulgular da benzer paralellikte olup tek eşik için kaydedilen $(126,55)^{\prime}$ 'lik değer, dağılımın \%5'lik değerinden; çift eşik için tespit edilen 
$(115,10)$ 'luk değer dağılımın \%1'lik kritik değerinden daha küçüktür. Yani, boş hipotez tek eşik için \%5, çift eşik için \%1 anlamlılık seviyesinde reddedilmektedir. Sağlamlık kontrolü için tercih edilen (GINI_MKT) değişkeni de enflasyon ile doğrusal olmayan bir ilişki içerisindedir.

Şekil: 1

Tek ve Çift Eşik için LR En Çok Olabilirlik İstatistikleri
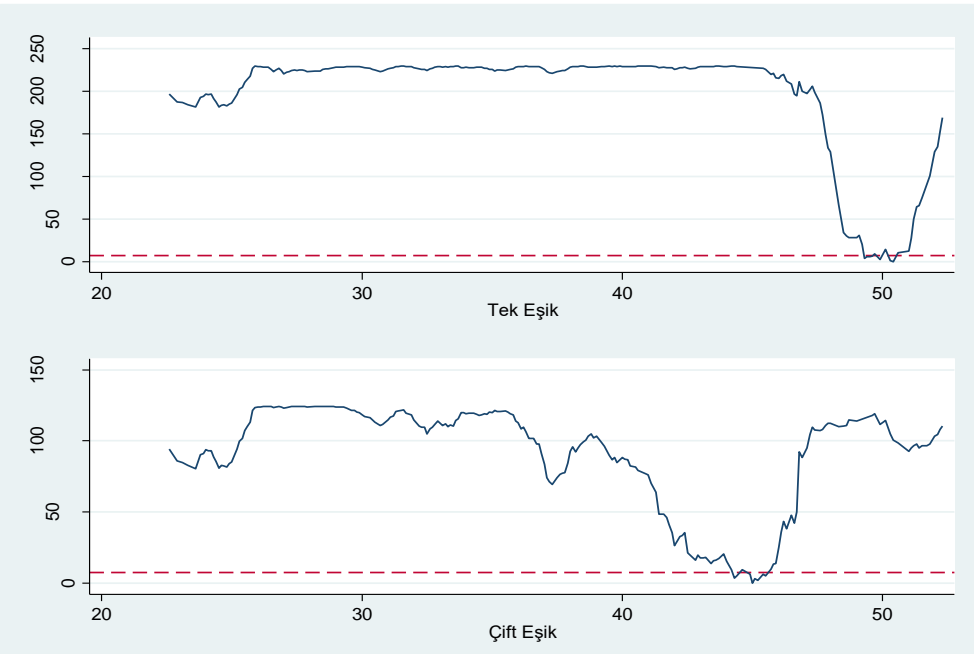

LR en çok olabilirlik istatistikleri, eşik değer testinde dağılımın güven aralıklarını tespit etmek için kullanılmaktadır. Şekil 1'deki kırmızı kesikli yatay çizgi, \%95 anlamlılık seviyesinin kritk değerini temsil etmektedir. Bu değer $(7,35)$ olarak gösterilmektedir. Modelde \%95 güven aralığı alt (lower) ve üst (upper) seviyeleri tek eşik için [49,200 ve 49,400] olarak tespit edilmektedir. En çok olabilirlik fonksiyonunu minimize eden ve en küçük kareler toplamı ile tahmin edilen eşik değer ise $(49,300)$ 'dür. Çift eşik için alt ve üst seviyeler [44,750 ve 45,100] olarak tespit edilmektedir. En çok olabilirlik fonksiyonunu minimize eden ve en küçük kareler toplamı ile tahmin edilen çift eşik değer ise $(45,000)$ 'dir. $\mathrm{Bu}$ eşik değerler her iki eşik için iki farklı rejimin varlığına dair kanıt sunmaktadır. Şekil 1 'de tek ve çift eşik parametre değerini temsil eden bu grafikler gösterilmektedir. Ek-2'de (GINI_MKT) değişkeni için alt ve üst seviyelerin resmedildiği LR en çok olabilirlik istatistikleri grafiği de yer almaktadır. Bu seviyeler tek eşik için [42,350 ve 42,600], çift eşik için $[51,650$ ve 51,900] olarak tespit edilmektedir. En çok olabilirlik fonksiyonunu minimize eden ve en küçük kareler toplamı ile tahmin edilen eşik değerler ise tek eşik için $(42,500)$, çift eşik için $(51,800)$ 'dür.

Tablo 6'da $\beta_{1}$ ve $\beta_{2}$, enflasyonun gelir eşitsizliği üzerindeki rejime bağlı etkisini temsil eden parametrelere karşılık gelen katsayılardır. Tek eşik için $(49,300)$, çift eşik için 
$(45,000)$ olan eşik enflasyon değerlerinin altında enflasyon gelir eşitsizliği ilişkisi ters yönlü (negatif) iken bu değerin üzerinde bir enflasyon oranı gelir eşitsizliğini aynı yönde (pozitif) etkilemektedir. Her iki parametre de istatistiki olarak güçlü derecede anlamlıdır $(0,003$ ve 0,010). Elde edilen bulguların Bulíŕ (2001), Galli \& Van der Hoeven (2001), Monnin (2014) ve Balcilar vd. (2018) ile ortaya koyulan ve Şekil 1'de de temsil edilen U -şekilli enflasyongelir eşitsizliği ilişkisi ile paralel olduğu görülmektedir. Ek-3'de (GINI_MKT) göstergesi ile gerçekleştirilen sağlamlık kontrolü analiz bulguları da yer almaktadır ve sonuçlar kontrol değişkenlerden biri olan (YATIRIM) değişkeni hariç paralellik göstermektedir. Bu sonuç, panele konu olan 40 adet ülke için bu değerlerin altında bir enflasyon (tüketici fiyat endeksi) oranının gelir elde eden bireyler ve/veya gelir grupları arasında (göreli) adil dağılımı sağladığına işaret etmektedir. Gerçekten de düşük bir enflasyon oranı hanehalkının ya da bireylerin satın alma gücünü olumlu etkileyebilir. Satın alma gücü artan bireylerin tüketim veya transferler yoluyla gelirin bireyler/gelir grupları arasında (adil) dağılımını veya birbirine aktarımını sağlaması, gelir eşitsizliğinin azaltılmasında rol oynayabilir.

Tablo: 6

\section{Enflasyonun Gelir Eşitsizliği Üzerindeki Rejim ve Kontrol Değişken Tahmini Sonuçları}

\begin{tabular}{|c|c|c|}
\hline \multicolumn{3}{|l|}{ Eşik Değer Tahmini } \\
\hline Tek Eşik Değer Parametresi & $49,300 * * *$ & $\sqrt{0,003}$ \\
\hline \%95 Güven Aralığı & \multicolumn{2}{|c|}{$[49,200$ ve 49,400$]$} \\
\hline $\begin{array}{l}\text { Çift Eşik Değer Parametresi } \\
\% 95 \text { Güven Aralıŏ } 1\end{array}$ & $\begin{array}{c}45,000^{* * *} \\
{[44,750 \text { ve } 45,100]}\end{array}$ & $\sqrt{ } 0,010$ \\
\hline \multicolumn{3}{|c|}{ Tek Eşik için Rejim Katsayıları (Enflasyonun Gelir Eşitsizliği Üzerindeki Etkisi) } \\
\hline$\beta_{1}$ & $-0,048$ **** $(0,004)$ & $\sqrt{0,000}$ \\
\hline$\beta_{2}$ & $0,022 * * *(0,002)$ & $\sqrt{0,000}$ \\
\hline \multicolumn{3}{|c|}{ Çift Eşik için Rejim Katsayıları (Enflasyonun Gelir Eşitsizliği Üzerindeki Etkisi) } \\
\hline$\beta_{1}$ & $-0,003 * * * *(0,002)$ & $\sqrt{0,000}$ \\
\hline$\beta_{2}$ & $0,057^{* * * *}(0,004)$ & $\sqrt{0,000}$ \\
\hline \multicolumn{3}{|l|}{ Kontrol Değişkenler } \\
\hline BUYUME & $2,216^{* * * *}(0,385)$ & $\sqrt{0,000}$ \\
\hline$\underline{I S S I Z L I K}$ & $0,145^{* * * *}(0,020)$ & $\sqrt{0,000}$ \\
\hline$\underline{A C I K L I K}$ & $-0,020$ ***** $(0,002)$ & $\sqrt{0,000}$ \\
\hline TUKETIM & $-1,954 * * * *(0,270)$ & $\sqrt{0,000}$ \\
\hline YATIRIM & $-0,404 * * *(0,238)$ & $\sqrt{0,090}$ \\
\hline$\underline{\underline{N}}$ & \multirow{2}{*}{\multicolumn{2}{|c|}{$\begin{array}{c}1080 \\
0,043[0,031 \text { ve } 0.397]\end{array}$}} \\
\hline$R-s q$ & & \\
\hline
\end{tabular}

Panele konu olan ülkelerin homojen tüketici fiyat endeski oranlarına sahip olmadıkları göz önüne alındığında, ülkelerin gelişmişlik seviyelerinin de önemli olduğu düşünülmektedir. Eşik tüketici fiyat endeksi seviyelerinin altında enflasyonun gelir eşitsizliği ile ters (negatif) yönlü ilişkisi, bu değerin üzerindeki pozitif yönlü ilişkisi, panele konu olan ülkeler için düşük ve yüksek enflasyon değerlerine politika yapıcıların farklı şekillerde önem vermesi gerekliliğini doğrulamaktadır. Yüksek bir enflasyon paranın satın alma gücünü düşürerek yaşam maliyetlerini artırmaktadır. Öte yandan, gelişmiş ve gelişmekte olan ülkeler açısından enflasyonun gelir eşitsizliği ile olan ilişkisi noktasında dikkate alınması gereken bazı hususlar vardır. Enflasyonun geliri, borçlu kesime doğru alacaklı kesimden alarak dağıttığını öngören borçlu-alacaklı hipotezi bu hususlardan bir 
Aktaş, E.E. \& S. Dokuzoğlu (2022), "Enflasyon-Gelir Eşitsizliği İlişkisi: Gelişmiş ve Gelişmekte Olan Ülkeler için Panel Eşik Değer Analizi”, Sosyoekonomi, 30(51), 449-470.

tanesidir. Gelişmekte olan ülkelerdeki düşük ve orta gelir grupları genel olarak borçlu kesimi oluşturmaktadır. Yüksek gelirliler ise bu ülkelerde alacaklı durumdadır. Bireyler yaşları ilerledikçe birikim yaparak ekonomik refah seviyelerini yükseltmektedir. Bireyler, görece gençken çalıştıkları için bu dönemde birikim yapıp borçlanmaktadır. Yani, bu kesimin enflasyona endeksli olmayan borçlarının reel değeri yüksek enflasyon sebebiyle azalabilmektedir. Başka bir deyişle enflasyon, ileri yaştaki kesimden orta yaştaki daha genç guruba; alacaklı kesimden borçlu kesime geliri yeniden dağıtmaktadır. Hâliyle her ne kadar yüksek enflasyon oranlarının gelir eşitsizliği ile ilişkisi önemli olsa da özellikle gelişmekte olan ülkelerin içlerinde bulunduğu yapısal durum, hem yüksek hem düşük enflasyon durumlarında dâhi bu hususların göz önünde bulundurulmasını gerekli kılmaktadır. Öte yandan, gelişmekte olan ülkelerde kamu borcu seviyesi de çok yüksek olabilir. Hükümetler bu durumda borcun reel değerini düşürmek için para basma yolunu tercih edebilmektedir. $\mathrm{Bu}$ durumda enflasyon yükselebilmektedir ve gelir, alacaklı konumundaki yüksek gelirlilerden hükümete doğru aktarılmaktadır.

( $\underline{\text { TUKETIM }}),(\underline{A C I K L I K})$ ve $(\underline{\text { YATIRIM }})$ değişkenleri ise gelir eşitsizliği ile negatif ilişkilidir. İktisat disiplini açısından önemli olan bireylerin tüketimi ya da harcamaları değil, tüm toplumun/devletin yaptığı tüketimlerdir/harcamalarıdır (Şengür \& Taban, 2016: 50). Bu sebeple, GSYH yüzdesi olarak nihai tüketim harcamaları analize dâhil edilmiştir. Bu harcama kalemi içinde larının gelir, tüketim, tasarruf tercihlerini önemli ölçüde etkileyen sosyal nitelikli harcamalar da bulunmaktadır. Bu noktada, hükümetin hangi gelir gruplarına dönük harcama yaptığı önem kazanmaktadır. Söz gelimi devletler, büyüme ve yatırım gibi çeşitli makroekonomik göstergelerde iyileşme sağlamak adına, geliri yüksek gelirlilere aktarabilir. Oysa ki, gelir eşitsizliğinin azaltılmasını hedefleyen bir politika, gelirin düşük ve orta gelir gruplarına aktarılarak bu gelir gruplarının harcama veya tüketim kararlarını etkilemeyi öncelemelidir. (ACIKLIK) ve (YATIRIM) değişkenlerinin negatif yönlü bulguları ve $(B U Y U M E)$ değişkeninin pozitif yönlü bulgusu da dikkate değerdir. Ekonomik büyümenin gelir eşitsizliği ile ilişkisi, Simon Kuznets'in ters U şekilli teorisinden bu yana sıklıkla tartışılmaktadır. Bazı gelişmekte olan ülkelerde büyüme ile gelir eşitisizliği arasında pozitif yönlü, bazı ülkelerde ve gelişmiş ekonomilerde negatif yönlü ilişki tespit edilmekte olup analiz bulgularının önceki literatür ile uyumlu olduğu görülmektedir. Dışa açıklığın ve sabit sermaye oluşumunun gelir eşitsizliği ile negatif yönlü ilişkisi; ihracat-ithalat dengesi, üretim faktörlerinin niteliği ve niceliği, işgücünün vasıflı olup olmaması, emeğin verimliliği, ekonominin emek ya da sermaye yoğun üretim yapısı, tarım veya sanayi sektöründeki yoğunlaşma, teknoloji transferi, ücretlerin seviyesi gibi pek çok kanal ile ilişkili değerlendirilmesi gereken bir bulgudur. Panele konu olan ülkelerin gelişmiş ve gelişmekte olan heterojen yapısı göz önüne alındığında, söz konusu kanalların ilişkiyi farklı yönde etkileyeceği açıktır. Her ne kadar bulgular, önceki literatür ile uyumlu olsa da gelecek çalışmalar açısından bu hususların araştırılması da önem arz etmektedir.

Öte yandan, $(\underline{I S S I Z L I K})$ değişkeninin gelir eşitsizliği üzerine etkisi pozitiftir. Artan gelir eşitsizliği bireylerin yoksullaşmasına sebep olur. Yoksullaşan bireyler ise işsizliğe karş1 duyarlı hâle gelecektir ve işgücüne katılma konusunda daha istekli olabileceklerdir. Ancak, eşitsizliğin azaltılması için gerekli olan istikrar politikalarının türü ve bu politikalar ile 
işgücü piyasası politikaları arasındaki etkileşim hususunda belirsizlikler vardır. Birincisi, istikrar araçlarının seçimi gelecekteki ekonomik büyüme ve istihdam yaratma etkileri bakımından farklı sonuçlara sahip olabilir. İkincisi, gelir eşitliği, siyasi belirsizlikten ve istikrar ömlemlerinden kimin fayda sağlayacağıyla ilgili anlaşmazlıkların çözülmesine katkıda bulunduğu için başarılı istikrar politikalarının gelir eşitsizliğinin azaltılmasına yardımcı olacağı hususudur (Van der Hoeven, 2000: 28). Rodrik (1998), ülkeler arası regresyon analizi aracılığıyla sosyal çatışma ve gelir dağılımı gibi değişkenlerin ülkelerin dış şoklar ile başa çıkma yetenekleri hakkında güçlü bir açıklama gücüne sahip olduğunu göstermiştir (Rodrik, 1998: 156). Bununla birlikte, işgücü piyasası esnekliği, kayıt dışı sektör istihdamının artması, asgari ücretlerin düşmesi, yüksek büyüme oranlarına sahip bazı ülkeler dışında gelir eşitsizliğini artırabilir. Bu nedenle, reform sürecinde işgücü piyasasında daha fazla eşitsizliğe yol açan, işgücü piyasasının yeniden dağıtım işlevine verilen önemin, büyümeyi teşvik etmek ve yoksulluğu azaltmak için tercih edilen politika aracı olmaması gerektiği sonucuna varılabilir. Esnek olmayan ücretler, (merkezi bir ücret politikası) işgücü piyasasının yeniden dağıtım işlevi üzerinde bir engel olarak düşünülebilir. Buna karşın, merkezi ücret belirlemenin daha düşük eşitsizliği ve daha düşük enflasyon oranlarını desteklediğine (eğer gerçek bir toplu pazarlık sürecinin sonucuysa) dair kanıtlar da mevcuttur (Van der Hoeven, 2000: 29-30). Fanelli \& Frenkel (1995), enflasyondaki bir düşüşün endüstrileri ve kurumları etkilediğini, bunun istihdam kapasitesine zarar verdiğini ve yenilenen enflasyon eğilimlerini güçlendirdiğini ileri sürmektedir (Fanelli \& Frenkel, 1995: 21). Amadeo (1996), enflasyonu düşürmek için döviz kurunu aşırı değerli tutmanın ve döviz kuru-baz istikrarının endüstriyel rekabet gücünde ve istihdamda bir kayba yol açabileceğini ileri sürmektedir (Amadeo, 1996: 1).

\section{Sonuç ve Değerlendirme}

Geçtiğimiz yıllar içerisinde makroekonomik politikaların gelir dağılımı boyutunu inceleyen çalışmaların sayısı artmıştır. Maliye ve para politikaları farklı makroekonomik hedeflere ulaşmada kullanılmakla birlikte yarattıkları sonuçlar ile gelir dağılımını değiştirebilmektedir. Literatürde gelirin yeniden dağıtımı olarak ifade edilen piyasa geliri ile harcanabilir gelirin farklılaşması durumu, genellikle hükümetlerin transfer, harcama, vergi ve istihdam politikaları ile ilişkilendirilmektedir. Söz konusu mali ve yarı-mali kanalların yanı sıra para politikası da enflasyon, gelir kompozisyonu, tasarruflar, faiz oranı, portföy kompozisyonu gibi kanallar ile geliri yeniden dağıtmaktadır. Özellikle son yıllarda enflasyonun gelir eşitsizliğini açıklayan bir değişken olarak sıklıkla analizlerde yer aldığ gözlemlenmektedir. Bazı çalışmalarda, bu etki belirsiz ve anlamsız olarak değerlendirilmiştir. Diğer yandan, enflasyonun gelir eşitsizliğini azalttığı veya artırdığ yönündeki bulgulara ulaşan çalışmalar da mevcuttur. Bununla birlikte, enflasyonun dağıtımsal etkilerinin doğrusal olmadığına işaret eden çalışmalar söz konusu etkinin dikkate alınmadığı durumlarda eksik veya tutarsız sonuçlar elde edilebileceğine işaret etmektedir.

$\mathrm{Bu}$ bağlamda, çalışmamız enflasyonun gelir dağılımı üzerindeki etkisini, 40 adet gelişmiş ve gelişmekte olan ülke ve 1993-2019 yıllarını kapsayan dönem için ortaya koymaktadır. İlk olarak, sabit etkiler modeli kullanılarak panel veri analizi gerçekleştirilmiş; 
Aktaş, E.E. \& S. Dokuzoğlu (2022), "Enflasyon-Gelir Eşitsizliği İlişkisi: Gelişmiş ve Gelişmekte Olan Ülkeler için Panel Eşik Değer Analizi”, Sosyoekonomi, 30(51), 449-470.

elde edilen bulguların doğrusal olmayan bir ilişkinin varlığına işaret edebileceği düşüncesiyle devamında Hansen (1999) panel sabit etkiler eşik değer analizi uygulanmıştır. Analiz sonuçları, enflasyon ve gelir eşitsizliği arasındaki doğrusal olmayan ilişkiyi doğrulamış ve tüketici fiyat endeksi cinsinden tanımlanan enflasyon değişkeni bakımından $(49,300)$ ve $(45,000)$ eşik değerleri saptanmıştır. Analizde bağımlı değişken olarak tanımlanan vergi ve transferler sonrası gelir eşitsizliği katsayısının yanında, sağlamlık kontrolü için vergi ve transferler öncesi gelir eşitsizliği katsayısı da yer almaktadır. Buna göre enflasyon-gelir eşitsizliği arasında, kritik eşiklerin altında ve üzerinde söz konusu ilişkinin yönü farklılaşmaktadır. Bir başka ifadeyle, enflasyon ve gelir eşitsizliği ilişkisinin yönünü enflasyon seviyesi belirlemektedir. Eşik değerin altında, enflasyon ve gelir eşitsizliği arasında ters yönlü, üzerinde ise aynı yönlü bir ilişkinin varlığı ortaya koyulmuştur. Panele konu ülkelerin gelişmiş ve gelişmekte olan, özdeş bir yapıda olmadığı göz önüne alındığında, analiz bulgularının dikkatli yorumlanması gerekmektedir. İster gelişmiş ister gelişmekte olan ülke olsun, herhangi bir ekonomide genel ekonomik denge ile makroekonomik göstergelerde bozulmaya yol açabilecek enflasyon olgusu, politika yapıcıların yoğunlaşması gereken önemli bir iktisadi husustur. Satın alma gücünü olumsuz etkileyip yaşam maliyetlerini artıran enflasyon, önlem alınmazsa başka birçok sorunu beraberinde getirebilmektedir. Öte yandan, fiyatlardaki artış, yeniden dağıtım etkisi yoluyla eşitsizliğin azalmasına da neden olabilir. Bu etkinin, daha müreffeh olan borç verenlerden daha az varlıklı borçlulara gerçek servet transferiyle sonuçlanan enflasyon kanalıyla ilişkili olup olmadığının tespiti gerekmektedir. Para otoritelerinin uygulayacağı enflasyon hedeflemesi politikası, enflasyondaki oynaklığı azaltmakta ve bu kanalın gelir eşitsizliği üzerindeki işleyişini sınırlandırmada önemli rol oynamaktadır. Aynı zamanda, fiyat istikrarının sağlanmasının bir sonucu olarak eşitsizlikteki artışın nicel tahminleri ülkeden ülkeye nispeten düşük kalabilmektedir. Bununla birlikte, enflasyonun yeniden dağıtım etkileri oldukça karmaşık olduğundan enflasyonun gelir dağılımı etkilerini yalnızca alacaklılardan borçlulara yeniden dağıtım şeklinde değerlendirmek de eksik olacaktır. Bunun nedeni, gelirin (ve servetin) enflasyona bağlı olarak yeniden dağıtılmasının kurumsal faktörler, paraya erişim, tüketim ve harcama sepetlerindeki farklılıklar veya ekonomik birimlerin varlık ve yükümlülüklerinin yapısı gibi birçok şeye bağlı olmasıdır. Başka bir deyişle, farklı grupların göreli gelir (ve servet) konumundaki değişiklikler, büyük ölçüde, malların ve varlıkların göreli fiyatlarındaki hareketlere, mal ve varlıkların mülkiyetindeki farklılıklara bağlıdır. Bu sebeple analize, diğer kontrol değişkenler de eklenmiştir ve bu değişkenlerin de bağımlı değişken gelir eşitsizliği ile ilişkisi beklentilere ve öngörülere uygundur. Gelecek çalışmaların, gelir eşitsizliği göstergesi ile ilişkili kısıtları gözeterek başka örneklemler için analizler gerçekleştirmesi, yeterli gözlem sayısına ulaşılması durumunda gelişmiş ve gelişmekte olan ülkelerin ayrı panellerde analiz edilmesi, metodolojik avantaj sağlayan başka yöntemlerin de analizlere dâhil edilmesi araştırma alanına olan katkıyı geliştirebilecektir. Gelir eşitisizliği gibi dağıtımsal etkileri ekonomi üzerinde farklı sonuçlar doğuran ve gecikme etkisi ile başka iktisadi göstergeleri etkilemesi muhtemel kanalların dinamik yapıdaki panel eşik modelleri ile tahminlenmesinin de araştırma alanını genişletebileceği düşünülmektedir. 
Aktaş, E.E. \& S. Dokuzoğlu (2022), "Enflasyon-Gelir Eşitsizliği İlişkisi: Gelişmiş ve Gelişmekte Olan Ülkeler için Panel Eşik Değer Analizi”, Sosyoekonomi, 30(51), 449-470.

\section{Kaynaklar}

Abdul, J. (2012), "Modeling Income Inequality and Openness in the Framework of Kuznets Curve: New Evidence from China", Economic Modelling, 29(2), 309-315.

Achdut, L. (1996), "Income Inequality, Income Composition and Macroeconomic Trends: Israel, 1979-93”, Economica, 63(250), 1-27.

Albanesi, S. (2007), "Inflation and Inequality”, Journal of Monetary Economics, 54(1), 1088-1114.

Amadeo, E.J.S. (1996), “The Knife-Edge of Exchange Rate-Based Stabilization Impacts on Growth, Employment and Wages", UNCTAD Review, 361, UN Conference on Trade and Development, Cenova.

Ang, J.B. (2010), "Finance and Inequality: The Case of India", Southern Economic Journal, 76(3), 738-761.

Argun, A.İ. (2016), "Gelişmekte Olan Ülkelerde Finansal Gelişme ve Gelir Eşitsizliği”, İstanbul Üniversitesi Sosyal Bilimler Dergisi, 2016(1), 61-74.

Atkinson, A. (1996), "Seeking to Explain the Distribution of Income", in: J. Hills (ed.), New Inequalities Cambridge: Cambridge University Press, 19-48.

Bach, G.L. \& A. Ando (1957), “The Redistributional Effects of Inflation”, The Review of Economics and Statistics, 39(1), 1-13.

Bai, J. \& P. Perron (1998), "Estimating and Testing Linear Models with Multiple Structural Changes", Econometrica, 66(1), 47-78.

Bai, J. (1997), "Estimating Multiple Breaks One at a Time”, Econometric Theory, 13(3), 315-352.

Balc1lar, M. et al. (2018), "The Relationship between the Inflation Rate and Inequality Across US States: A Semiparametric Approach", Quality \& Quantity, 52(5), 2413-2425.

Björklund, A. (1991), "Unemployment and Income Distribution: Time-Series Evidence from Sweden", Scandinavian Journal of Economics, 93(3), 457-465.

Blejer, M. \& I. Guerrero (1990), “The Impact of Macroeconomic Policies on Income Distribution: An Empirical Study of the Philippines", The Review of Economics and Statistics, 72(3), 414-423.

Bulír, A. (2001), “Income Inequality: Does Inflation Matter?”, IMF Staff Papers, 48(1), 139-159.

Caminada, K. et al. (2017), "Income Inequality and Fiscal Redistribution in 47 LIS-Countries 19672014", LIS Working Paper Series, 724, Luxembourg Income Study Cross-National Data Center, Luxembourg.

Chan, K.S. (1993), "Consistency and Limiting Distribution of the Least Squares Estimator of a Threshold Autoregressive Model”, Annals of Statistics, 21(1), 520-533.

Chatterjee, S. \& D. Corbae, (1992), "Endogenous Market Participation and the General Equilibrium Value of Money", Journal of Political Economy, 100(3), 615-646.

Chu, K.-Y. et al. (2000), "Income Distribution and Tax, and Government Social Spending Policies in Developing Countries", UNI/WIDER Working Papers, 214, UNU World Institute for Deevelopment Economics Research, Helsinki.

Colciago, A. et al. (2019), "Central Bank Policies and Income and Wealth Inequality: A Survey", Journal of Economic Surveys, 33(4), 1199-1231.

Doepke, M. \& M. Schneider (2006), "Inflation and the Redistribution of Nominal Wealth", Journal of Political Economy, 114(6), 1069-1097. 
Dolmas, J. et al. (2000), "Inequality, Inflation, and Central Bank Independence”, The Canadian Journal of Economics, 33(1), 271-287.

Easterly, W. \& S. Fischer (2001), "Inflation and the Poor", Journal of Money, Credit and Banking, 33(2), 160-178.

Erosa, A. \& G. Ventura (2002), “On Inflation as A Regressive Consumption Tax”, Journal of Monetary Economics, 49(4), 761-795.

Fanelli, J.M. \& R. Frankel (1995), Micro-Macro Interaction in Economic Development, <https://repositorio.cedes.org/handle/123456789/3924>, 19.04.2021.

Fischer, S. \& F. Modigliani (1978), "Towards An Understanding of the Real Effects and Costs of Inflation", Review of World Economics, 114(4), 810-833.

Franco, C. \& E. Gerussi (2013), "Trade, Foreign Direct Investments (FDI) and Income Inequality: Empirical Evidence from Transition Countries", The Journal of International Trade \& Economic Development, 22(8), 1131-1160.

Galli, R. \& R. Van der Hoeven (2001), "Is Inflation Bad for Income Inequality: The Importance of the Initial Rate of Inflation”, ILO Employment Paper, 2001/29, ILO, Cenova.

Gottschalk, P. \& T. Smeeding (1997), "Cross-National Comparisons of Eamings and Income Inequality”, Journal of Economic Literature, 35(2), 633-687.

Gülmez, A. \& N. Altıntaş (2015), “Türkiye'de Ticari Açıklık ve Enflasyonun Gelir Dağılımına Etkisi: Ekonometrik Bir Analiz”, Kafkas Üniversitesi İIBF, 6(9), 31-44.

Hansen, B.E. (1999), "Threshold Effects in Non-Dynamic Panels: Estimation, Testing, and Inference", Journal of Econometrics, 93(2), 345-368.

Jäntti, M. \& S.P. Jenkins (2010), “The Impact of Macroeconomic Conditions on Income Inequality”, The Journal of Economic Inequality, 8(2), 221-240.

Kane, C.T. \& J. Morisset (1993), "Who Would Vote for Inflation in Brazil?: An Integrated Framework Approach to Inflation and Income Distribution”, Policy Research Working Paper Series, 1183, The World Bank.

Kuznets, S. (1955), "Economic Growth and Income Inequality", The American Economic Review, 45(1), 1-28.

Meh, C. \& Y. Terajima (2009), "Unexpected Inflation and Redistribution of Wealth in Canada", Bank of Canada Review, 2009(Spring), 45-52.

Meh, C. \& Y. Terajima (2010), "Aggregate and Welfare Effects of Redistribution of Wealth under Inflation and Price-Level Targeting", Journal of Monetary Economics, 57(6), 637-652.

Menna, T. \& P. Tirelli (2017), "Optimal Inflation to Reduce Inequality”, Review of Economic Dynamics, 24(2), 79-94.

Milanovic, B. (1994), "Determinants of Cross-Country Income Inequality: An Augmented Kuznets Hypothesis", World Bank Policy Research Working Paper, 1246, World Bank Group, Washington, D.C.

Monnin, P. (2014), "Inflation and Income Inequality in Developed Economies", CEP Working Paper Series, 2014/1, Council on Economic Policies, Zurich.

Mumtaz, H. \& A. Theophilopoulou (2017), "The Impact of Monetary Policy on Inequality in the UK: An Empirical Analysis”, European Economic Review, 98(8), 410-423. 
Nolan, B. (1988), "Macroeconomic Conditions and the Size Distribution of Income: Evidence from the United Kingdom", Journal of Post Keynesian Economics, 11(2), 196-221.

Park, C-Y. \& R.V.Jr. Mercado (2015), "Financial Inclusion, Poverty, and Income Inequality in Developing Asia", ADB Economics Working Paper Series, 426, Asian Development Bank, Tokyo, Japan.

Ribba, A. (2003), "Short-Run and Long-Run Interaction Between Inflation and Unemployment in the USA", Applied Economics Letters, 10(6), 373-376.

Rodrik, D. (1998), “Globalisation, Social Conflict and Economic Growth”, The World Economy, 21(2), 143-158.

Romer, C.D. \& D.H. Romer (1998), "Monetary Policy and the Well-Being of the Poor", NBER Working Paper, 6793, National Bureau of Economic Research, Cambridge, Mass.

Şengür, M. \& S. Taban (2016), “Gelir Dağılımı-Tasarruf İlişkisi: Türkiye'de Gelir Türünün Tasarruflar Üzerindeki Etkisi”, Anadolu Üniversitesi Sosyal Bilimler Dergisi, 16(1), 4971.

Shahbaz, M. \& F. Islam (2011), "Financial Development and Income Inequality in Pakistan: An Application of ARDL Approach", MPRA Paper Series, 28222, Munich Personal RePEc Archive, Utah, USA.

Shahbaz, M. et al. (2015), "Financial Development and Income Inequality: Is there any Financial Kuznets Curve in Iran", Social Indicators Research, 124(2), 357-382.

Sieroń, A. (2017), "Inflation and Income Inequality", Prague Economic Papers, 26(6), 633-645.

Solt, F. (2020), "Measuring Income Inequality Across Countries and Over Time: The Standardized World Income Inequality Database”, Social Science Quarterly, 101(3), 1183-1189.

Sturzenegger, F. (1992), "Inflation and Social Welfare in a Model with Endogenous Financial Adaptation", NBER Working Paper, 4103, National Bureau of Economic Research, Cambridge, Mass.

Sun, H. (2011), Search, Distributions, Monetary and Fiscal Policy, Kingston: Queen's University, Department of Economics, <https://www.chicagofed.org/events/2011/index>, 17.04.2021.

Thalassinos, E. et al. (2012), "Income Inequality and Inflation in the EU”, European Research Studies Journal, 15(1), 127-140.

Topuz, S.G. \& Ö. Dağdemir (2016), "Finansal Gelişme ve Gelir Eşitsizliği: Bir Panel Veri Analizi”, Anadolu Üniversitesi Sosyal Bilimler Dergisi, 16(3), 19-34.

Ün, T. (2018), "Stata ve Panel Modellerinin Tahmini”, içinde: S. Güriş (ed.), Uygulamalı Panel Veri Ekonometrisi, İstanbul: Der Yayınları, 43-72.

Van der Hoeven, R. (2000), "Labour Markets and Income Inequality What are the New Insights after the Washington Consensus?", UNI/WIDER Working Papers, 209, UNU World Institute for Deevelopment Economics Research, Helsinki.

Wang, Q. (2015), “Fixed-Effect Panel Threshold Model Using Stata”, The Stata Journal, 15(1), 121 134.

Wolff, E.N. (1979), "The Distributional Effects of the 1969-75 Inflation on Holdings of Household Wealth in the United States", Review of Income and Wealth, 25(2), 195-207.

Zheng, Z. (2020), "Inflation and Income Inequality in a Schumpeterian Economy with Menu Costs", Economic Letters, 186(1), 1-5. 


\section{Ek: 1}

(GINI_MKT) Bağımlı Değişkeni ile Yapılan Tek ve Çok Eşik Etki Testi Bulguları

\begin{tabular}{|c|c|c|c|c|c|}
\hline \multirow{2}{*}{ Eşik Değer } & \multirow{2}{*}{$\boldsymbol{F}$ İstatistiği } & \multirow{2}{*}{ Değeri } & \multicolumn{3}{|c|}{ Kritik Değerler } \\
\hline 42,500 & 126,55 & $\sqrt{ } 0,053^{*}$ & 104,855 & 128,141 & $\mathbf{\% 1}$ \\
\hline 51,800 & 115,10 & $\sqrt{ } 0,013^{*}$ & 76,911 & 92,149 & 115,325 \\
\hline 47,300 & 69,16 & $X 0,483^{*}$ & 116,827 & 138,245 & 194,080 \\
\hline
\end{tabular}

Not: * bootstrap (300) tekrarlı olasılık dağılımını göstermektedir. Xilişkinin anlamsız olduğunu, $\sqrt{\text { ilişkinin anlamlı }}$ olduğunu göstermektedir.

Ek: 2

\section{(GINI_MKT) Bağımlı Değişkeni ile Yapılan Tek ve Çift Eşik için LR En Çok Olabilirlik İstatistikleri}

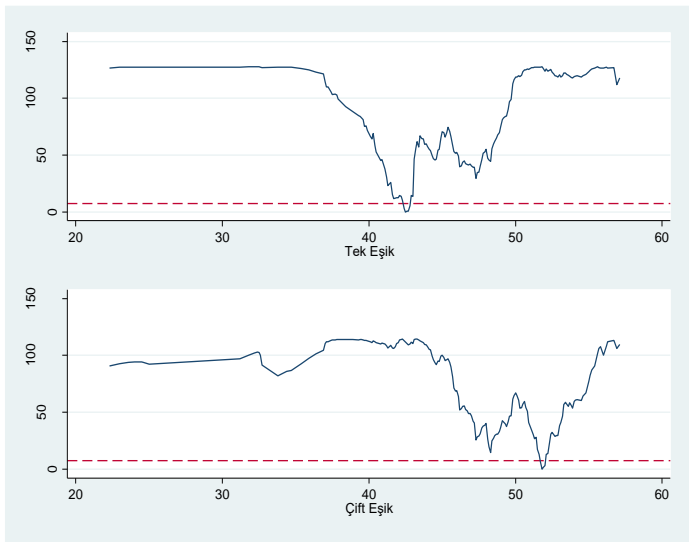

Ek: 3

Enflasyonun Gelir Eşitsizliği Üzerindeki Rejim ve Kontrol Değişken Tahmini Sonuçları (GINI_MKT)

\begin{tabular}{|c|c|c|}
\hline Eşik Değer Tahmini & & \\
\hline Tek Eşik Değer Parametresi & $42,500^{* * *}$ & $\sqrt{0,053}$ \\
\hline$\% 95$ Güven Aralığ1 & {$[42,350$} & \\
\hline $\begin{array}{l}\text { Çift Eşik Değer Parametresi } \\
\% 95 \text { Güven Aralığı }\end{array}$ & $\begin{array}{c}51,800^{* *} \\
{[51,650 \text { ve } 51,900]}\end{array}$ & $\sqrt{ } 0,013$ \\
\hline Tek Eşik için Rejim Katsayt & & \\
\hline$\beta_{1}$ & $-0,032 * * *(0,002)$ & $\sqrt{0,000}$ \\
\hline$\beta_{2}$ & $0,013 * * *(0,002)$ & $\sqrt{0,000}$ \\
\hline Çift Eşik için Rejim Katsayt & & \\
\hline$\beta_{1}$ & $-0,000 * * *(0,002)$ & $\sqrt{0,000}$ \\
\hline$\beta_{2}$ & $0,023 * * *(0,003)$ & $\sqrt{0,000}$ \\
\hline Kontrol Değişkenler & & \\
\hline$\underline{B U Y U M E}$ & $1,587 * * *(0,407)$ & $\sqrt{0,000}$ \\
\hline ISSIZLIK & $0,153 * * *(0,021)$ & $\sqrt{0,000}$ \\
\hline$A C I K L I K$ & $-0,023^{* * *}(0,002)$ & $\sqrt{0,000}$ \\
\hline TUKETIM & $-1,294 * * *(0,287)$ & $\sqrt{0,000}$ \\
\hline YATIRIM & $-0,129(0,251)$ & $\mathrm{X} 0,608$ \\
\hline$\underline{N}$ & & \\
\hline$\underline{R-s q}$ & $0,187[0$, & \\
\hline
\end{tabular}

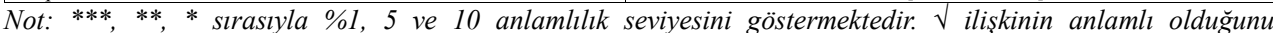
belirtmektedir. Parantez içindeki değerler standart sapmaları, parantezden önceki değerler katsayıları ifade etmektedir. 